\title{
Araucaria: A Relict Genus
}

\author{
Teena Agrawal* \\ Banasthali University, Rajasthan, India
}

*Corresponding author: Teena Agrawal, Banasthali University, Rajasthan, India, Tel: +91-9680724243; E-mail: tagrawal02@gmail.com

Received Date: August 10, 2017; Accepted Date: November 09, 2017; Published Date: November 12, 2017

Copyright: (C) 2017 Agrawal T. This is an open-access article distributed under the terms of the Creative Commons Attribution License; which permits unrestricted use; distribution; and reproduction in any medium; provided the original author and source are credited.

Citation: Agrawal T (2017) Araucaria: A Relict Genus. Br J Res Vol.4 No 5: 30.

\section{Abstract}

Gymnosperms have very important phylogenetic values among the all plants group. They are intermediate among the top of the angiosperms and the other lower plant group. This group shows tremendous kind of development in Mesozoic era. However; at the end of the cretaceous one can see the rapid decline in the species. Araucaria is the genus of the great values. They have the reservoirs of the many conserved sequences which show the clear pathways of the evolution. New Caledonia near Australia is a heaven of Araucaria. Near Chile the tribal people use those plants for several purposes. This is the best ornamental tree and this plant is near the edges of the extinction. So internationally efforts are needed for saving these plants.

\section{Keywords: Gymnosperms; Extinction; Sequences;}

Conserved; Araucaria

\section{Introduction}

Gymnosperms are the naked seeds plants [1,2]. They are the top most evolutionary conserved flora of the plant kingdom. The combination of the features is like that they approached the maximum of the evolution. However in angiosperm one can see the height of evolution of all organs and genera's. Coniferales are the living representatives of the gymnosperms, although Cycadales are also the relict liens of the evolution, however coniferales are the only lines of the evolution which needs conservation and it is the reservoirs of the all kinds of the genes and there metabolites sources [1-3].

Araucaria is the evergreen genus of the family Arucariaceae. In whole world around 20 species of the Araucaria has been reported. New Caledonia is the place which is the heaven for the Araucaria [1-3]. Maximum genetic diversity has been seen in that area of Australia the island is isolated and there is not any much anthropogenic disturbances so maximum kinds of the diversity can be seen in that island. However maximum diversity was seen in the Jurassic period. A long forest ecosystem of the araucaria can be seen over there. The development of araucaria correlates with the development of the reptiles of that area and era (Figures 1 and 2) [1-3]. On the basis of mt-DNA and nuclear DNA it was conferred that there are four basic lines of evolution in araucaria plants lines or the cladistics of the Araucaria, these cladistics are enlisted as:

- Araucaria

- Bunya

- Intermedia

- Eutacta

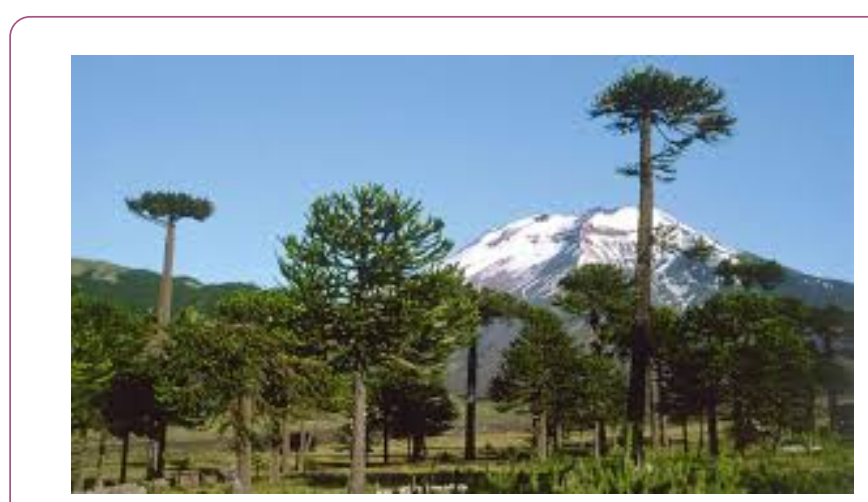

Figure 1. Araucaria forest in New Caledonia (sources gymnosperm databases).

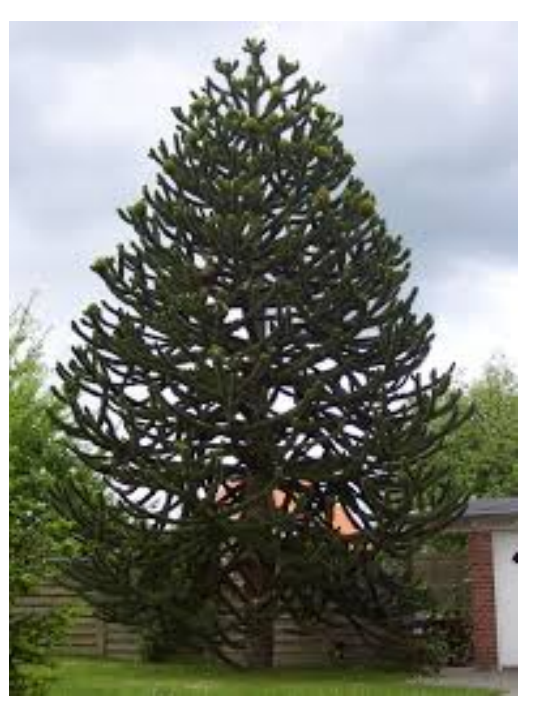

Figure 2. Araucaria tree (sources Arnold arboretum). 
Stem of the tree is cylindrical and it is typical premedical and looks very beautify cones. The branches are long cylindrical and tapering at the end. The wood have the typical gymnosperms kinds of the wood anatomy, however xylem and phloem are totally devoid of the vessels and the sieve tube elements completely respectively [1-3].

Leaves are Microphylles, juvenile leaves of the araucaria most commonly seen as in the double rows spirally arranged. The leaves anatomy is suitable for the xeric conditions. The araucaria grows well in the lower altitudes with good rainfalls [1-3].

Cones are the most important part of the genus. Majority of the species are dioeciously. However in some species both cones can be found on the same plant.

In China two species of the Araucaria has been revised $[2,3]$.

Indigenous peoples of the Chile utilize the araucaria for the variety of the purposes (Thora martina et al.). Araucaria is the most important endemic tree of the Chile and sometime it is the most endangered, tree species of the Chile. Here is the Andes mountain series, which is the homeland of the many tribal peoples. Here mapaucue penuche people use the araucaria for their livelihood purposes. They have the social, economic and the religious relationship with the Araucaria trees [4].

\section{Uses of Araucaria}

Economically the plant is very useful and all the plant part is of commercial value. In Australia the wood is used for the construction of the many houses and inside luxury.

- The plant is useful for ornamentation purposes.

- In home it is used for the aesthetic values.

- The seed are used as a food, in most of the part of the world.

- The flower buds also of the medicinal value.

- The wood is very useful economically\& commercially.

Phytochemistry, the Araucaria has been worked out by many workers of the different part of the globe. All plant parts are the reservoirs of many kinds of metabolites and of medical values.

Phytochemistry of A. columanis has been worked out by many workers in the different part of the world [5].

Used the dichloromethane and the methanol for the separation of compounds, thin layer chromatography (TLC) is used as the separation of the compounds, as an analytical techniques for the isolation and the identification of the various compounds. Phytochemical analysis shows the presence of the tannins and the glycosides [3].

Chemical and the biological investigations of Araucaria heterophylla has been investigated by Satter et al

Three labdanae diterpene has been identified by $\mathrm{H}$, NMR CNMR.

Bioflavonoids of the Araucaria have been investigated by the Khan et al.

Evolutionary diversification of the New Caledonia Araucaria species has been investigated by the Mai-lankrantiz et al. On the basis of the mt-DNA and the nuclear DNA it has estimated that this genus has the most conserved sequences in the evolution .They represent the relict lines of the evolution [1-3]. In world only the New Caledonia is the site where this genus is endemic, otherwise the other part of the world this genus is in endemic state.

However since the habitat in the other part of the world these lines of the evolution are degrading with the great speed. In world only the New Caledonia site help lace where this genus is endemic, otherwise the other part of the world this genus is in the lines of the extinction. Araucaria represents the combinations of the genes of the fossil gymnosperms.

These plant lines of the evolution are very important form the analysis of the evolution and the phylogenetic of the gymnosperm. The all plant part is the reservoirs of the metabolites of the medicinal values.

So IUCN and the Indian govt. efforts are needed for the conservation of these liens of the evolution.

\section{References}

1. Thomas P (2010) Araucaria subulata. The IUCN Red List of Threatened Species.

2. Gymnosperm databases.

3. Thomas P (2011) Araucaria cunninghamii. The IUCN Red List of Threatened Species.

4. Thomas P (2011) Araucaria heterophylla. The IUCN Red List of Threatened Species.

5. Thomas P (2017) Araucaria goroensis. The IUCN Red List of Threatened Species. 